\title{
Laryngeal Cancer pN0 TNM Finding v8
}

National Cancer Institute

\section{Source}

National Cancer Institute. Laryngeal Cancer pNo TNM Finding v8. NCI Thesaurus. Code C133141.

Laryngeal cancer with no metastasis to regional lymph nodes. (from AJCC 8th Ed.) 